\title{
The Perception of Corruption Among Retailers in Central Asia and Eastern Europe During and After the 2008 Crisis
}

\author{
https://doi.org/10.21272/sec.5(2).70-80.2021
}

Halil Dincer Kaya, ORCID: https://orcid.org/0000-0002-7535-9857

Professor of Finance, Department of Accounting and Finance, College of Business and Technology, Northeastern State University, Broken Arrow, OK, USA

Engku Ngah S. Engkuchik, ORCID: https://orcid.org/0000-0003-4625-4252

Assistant Professor of Finance, Prince Sultan University, Kingdom of Saudi Arabia

\begin{abstract}
In this study, we examine how the 2008-2009 Global Crisis has affected the informal payments/gifts paid by retailers in Eastern Europe and Central Asia. We look at the overall incidence of bribes, the incidence of bribes in customs/imports, the incidence of bribes in courts, and the incidence of bribes in tax payments. We compare the crisis period to the post-crisis period and found that these firms believed that the incidence of bribes went down significantly after the crisis ended. When we differentiate the retailers with respect to size, structure, legal form, gender of the owners, gender of the top manager, and whether or not they held an international quality certification, we found that, the results hold for all classifications of retailers. When we go into more detail and examine the incidence of bribes in customs/imports, courts, and taxes/tax collection, we found that the respondents saw a significant drop in the incidence of bribes in all areas after the crisis ended. However, our results show that, for bribes in customs/imports, the results do not hold for some of the classifications (i.e. medium-sized and the largest small firms, the firms that are part of a larger firm, the shareholding firms trading in the market, the partnerships, and the firms with an internationally recognized quality certification). For bribes in courts, the results do not hold for the largest small firms and the partnerships. For bribes in taxes/tax collection, the results do not hold for the partnerships and the firms with a quality certification. Our findings are consistent with the low rankings of these countries in Transparency International's annual Corruption Perception Index data. Our findings are also consistent with previous studies' findings that document high-levels of corruption in developing (or less developed) nations.
\end{abstract}

Keywords: bribe, bribery, corruption, informal payment, gift, retailer, global crisis, financial crisis.

Classification JEL: E01, D72, D73.

Cite as: Kaya, H.D., Engkuchik, E.N.S. (2021). The Perception of Corruption Among Retailers in Central Asia and Eastern Europe During and After the 2008 Crisis. SocioEconomic Challenges, 5(2), 70-80.

https://doi.org/10.21272/sec.5(2).70-80.2021

Received: 31.03 .2021

Accepted: 23.06.2021

Published: 25.06 .2021

Copyright: (C) 2021 by the author. Licensee Sumy State University, Ukraine. This article is an open access article distributed under the terms and conditions of the Creative Commons Attribution (CC BY) license (https://creativecommons.org/licenses/by/4.0/).

\section{Introduction}

In this study, we employ the Business Environment and Enterprise Performance Survey (i.e. BEEPSII and BEEPSIV surveys) which are conducted and made public by the European Bank for Reconstruction and Development (EBRD) in collaboration with the World Bank Group (WBG) and the European Investment Bank (EIB), and examine the impact of the 2008-2009 Global Crisis on the informal payments or gifts paid by retail companies in 29 Eastern European and Central Asian countries. Countries in these two regions consistently have 
very low rankings in the Corruption Perceptions Index (CPI) - an index which indicates the corruption level in each country and published annually by Transparency International. For example, the average CPI score of these countries was approximately 35 and 36 points in 2008 and 2013 respectively, compared to the average score of other European countries which exceeded 70 points during the same period. Based on the CPI published in 2019, the Eastern European and Central Asian regions together remained one of the worst performing regions (with an average score of 35), which was slightly better than only Sub-Saharan Africa (32 points), and worse than the Middle East and North Africa (39 points).

As such, corruption is perceived to be a common phenomenon in developing and less developed countries (see e.g. Tanzi and Davoodi, 1997; Leite and Weidmann, 1999; Henderson and Kuncoro, 2004; Kronenberg, 2004; Osei-Tutu et al., 2010; Tonoyan, 2010; and Kapur and Vaishnav, 2013), and is synonymous with bureaucracy and interactions between businesses and citizens with government or public officials, and is most prevalent when there are other forms of institutional inefficiency such as political instability, bureaucratic red tape, and weak legislative and judicial systems (see e.g. Mauro, 1998; Aidt, 2003; Drury, 2006; Glaeser, 2006; Anokhin and Schulze, 2009; Pellegrini, 2011).

Since a crisis is associated with harsher economic conditions and an unfavorable environment for retailers, we expect more incidence of bribes or corruption by the retailers during this period. As things improve after the crisis, we expect to see fewer bribe incidences. In this study therefore, we address four questions, including: Did the overall incidence of bribes went down after the crisis ended? Did the incidence of bribes in customs/imports went down after the crisis ended? Did the incidence of bribes in courts went down after the crisis ended? Did the incidence of bribes in taxes and tax collection went down after the crisis ended?

This study indicates that in general, for retail firms in the sample countries, respondents believed that bribes were more common during the crisis than after the crisis, regardless of the type of the bribes (i.e. customs/imports, courts, and taxes/tax collection) and characteristics of the firms (e.g. firm size, legal status, gender of owners or top manager, holding quality certification, and part of larger firm). However, the results do not hold for some of the classifications (i.e. the medium-sized and the largest small firms, the firms that are part of a larger firm, the shareholding firms trading in the market, the partnerships, and the firms with an internationally recognized quality certification). In addition, for bribes in courts, the results do not hold for the largest small firms and the partnerships, whereas for bribes in taxes/tax collection, the results also do not hold for the partnerships and the firms with a quality certification.

The paper proceeds as follows: Section 2 discusses the previous literature. Section 3 explains our hypotheses. Section 4 describes the data. Section 5 shows the empirical results. Finally, Section 6 concludes.

\section{Literature Review}

Corruption has been defined as an extra-legal institution used by individuals or groups to gain influence over the actions of the bureaucracy. It is also defined as the abuse of public offices or crime of public officials for their own private or personal gain. In other words, corruption is the behavior that violates the trust placed in public officials and services to undermine the foundation on which generalized interpersonal trust lies (see e.g. Mauro, 1998; Aidt, 2003; Drury, 2006; Glaeser, 2006; Anokhin and Schulze, 2009; and Pellegrini, 2011). Corruption is also thought to be more common in developing countries as shown in several papers which have investigated this phenomenon, e.g. Tanzi and Davoodi (1997), Leite and Weidmann (1999), Henderson and Kuncoro (2004), Kronenberg (2004), Osei-Tutu et al. (2010), and Kapur and Vaishnav (2013). Tonoyan et al. (2010) suggest that countries with centralized economies and a larger amount of government intervention have a higher rate of corruption.

Mauro (1998) suggests that corruption is likely to occur where restrictions and government intervention such as in trade restrictions, subsidies, tax deductions, price controls, foreign exchange allocation schemes, and government-controlled provision of credit can lead to excessive profits. Mbaku (1996) finds that due to the inherent corruption, businesses devote a significant amount of resources to lobby and bribe politicians in order to maximize profit, creating an economy where businesses with the most power will flourish while smaller 
businesses will encounter extreme competition from the monopolies created by such practice. Mehnaz et al. (2001) find that more profitable companies are targeted at a higher rate regardless of size, which results in smaller businesses struggling against the same extortion that larger firms could handle better because of their size advantage.

As bad as it may be, Gould and Amaro-Reyes (1983) suggests that although corruption (e.g. via payoffs and kickbacks) can be costly, there can be benefits too, e.g. to help cut bureaucratic red tape, to expedite transactions, as well as to promote efficient entrepreneurial behavior by awarding contracts, licenses, and favors to the most efficient and enterprising capitalist who can offer the highest bribe. Svensson (2005) and Jain (2001) seem to concur that there is a positive relationship between corruption and economic or entrepreneurial growth. However, Bardhan (1997) and Ngunjiri (2010) suggest that corruption may hinder growth since entrepreneurs are at the mercy of corrupt public officials.

\section{Hypotheses}

Since the macroeconomic environment was very unfavorable for the retailers during the crisis period, this harsher competitive environment is expected to lead to more corruption (i.e. bribes) by the retailers. For the post-crisis period, we expect to see things to improve, therefore we expect to see fewer bribes after the crisis ended (i.e. the macroeconomic environment improved plus the governments' efforts should have also curbed down these types of activities over time). Therefore, our first hypothesis on the general incidence of bribery by retailers is as follows:

Hypothesis 1: For retailers, the overall incidence of bribes went down after the crisis ended.

With respect to bribery in different areas (i.e. customs/imports, courts, and taxes/tax collection), we expect the same trend. We expect to see more bribery during the crisis period and less bribery after the crisis ended. Therefore, our hypotheses on bribery in these different areas are as follows:

Hypothesis 2: For retailers, the incidence of bribes in customs/imports went down after the crisis ended.

Hypothesis 3: For retailers, the incidence of bribes in courts went down after the crisis ended.

Hypothesis 4: For retailers, the incidence of bribes in taxes and tax collection went down after the crisis ended.

In the next section, we explain our data and our variables.

\section{Data}

Every few years, the European Bank for Reconstruction and Development (EBRD) in collaboration with the World Bank Group (WBG) and the European Investment Bank (EIB) conducted the Business Environment and Enterprise Performance Survey (or BEEPS) in countries of Eastern Europe and Central Asia. The survey comprises companies from twenty-nine countries in Eastern Europe and Central Asia, including Albania, Armenia, Azerbaijan, Belarus, Bosnia and Herzegovina, Bulgaria, Croatia, Czech Republic, Estonia, FYR Macedonia, Georgia, Hungary, Kazakhstan, Kosovo, Kyrgyz Republic, Latvia, Lithuania, Moldova, Mongolia, Montenegro, Poland, Romania, Serbia, Slovak Republic, Slovenia, Tajikistan, Turkey, Ukraine, and Uzbekistan. Therefore, in this study, we use the BEEPSII and BEEPSIV surveys during the crisis (2008) and after the crisis (2013). The surveys include more than 2,300 and 2,600 retail companies in 2008 and 2013 respectively, as shown in Table 1.

Table 1. Summary Statistics for Retailers

\begin{tabular}{|c|c|c|c|c|c|c|}
\hline & \multicolumn{3}{|c|}{2008} & \multicolumn{3}{|c|}{2013} \\
\hline & $\mathbf{N}$ & Mean & Std & $\mathbf{N}$ & Mean & Std \\
\hline \multicolumn{7}{|l|}{ Panel A. } \\
\hline Common to pay additional payments/gifts & 2,314 & 2.16 & 1.36 & 2,647 & 1.79 & 1.09 \\
\hline \multicolumn{7}{|l|}{ Panel B. } \\
\hline Pay to deal with customs/imports & 2,115 & 1.61 & 1.14 & 2,550 & 1.50 & 0.99 \\
\hline Pay to deal with courts & 2,119 & 1.57 & 1.13 & 2,538 & 1.40 & 0.85 \\
\hline Pay to deal with taxes and tax collection & 2,231 & 1.80 & 1.22 & 2,596 & 1.57 & 1.00 \\
\hline
\end{tabular}

Sources: Authors' own work. Never is 1, Seldom is 2, Sometimes is 3, Frequently is 4, Usually is 5, Always is 6. 


\section{Empirical Results}

Table 2 shows the results of the responses given to question 1. We report the means for 2008 and 2013 as well as the p-values for the Mann-Whitney-Wilcoxon tests that compare the 2008 responses to the 2013 responses.

Table 2. Common for Retailers to Pay Additional Payments/Gifts?

\begin{tabular}{|c|c|c|c|}
\hline \multicolumn{4}{|c|}{ Wilcoxon Test } \\
\hline & 2008 & 2013 & p-value \\
\hline all & 2.16 & 1.79 & $<0.0001$ \\
\hline employees5-19 & 2.19 & 1.77 & $<0.0001$ \\
\hline employees20-99 & 2.09 & 1.80 & $<0.0001$ \\
\hline employees $>99$ & 2.19 & 1.79 & 0.0002 \\
\hline part of a larger firm & 2.08 & 1.80 & 0.0041 \\
\hline not part of a larger firm & 2.17 & 1.79 & $<0.0001$ \\
\hline shareholding firm trading in the stock market & 2.30 & 1.76 & 0.0123 \\
\hline shareholding firm shares traded privately & 2.16 & 1.82 & $<0.0001$ \\
\hline sole proprietorship & 2.06 & 1.80 & 0.0091 \\
\hline partnership & 2.09 & 1.58 & 0.0094 \\
\hline limited partnership & 2.36 & 1.18 & $<0.0001$ \\
\hline other & 2.00 & 1.68 & 0.0291 \\
\hline one or more female owner & 2.15 & 1.75 & $<0.0001$ \\
\hline no female owner & 2.18 & 1.82 & $<0.0001$ \\
\hline top manager female & 2.16 & 1.78 & $<0.0001$ \\
\hline top manager not female & 2.16 & 1.80 & $<0.0001$ \\
\hline firm without an intl recog. quality certification & 2.16 & 1.77 & $<0.0001$ \\
\hline firm with an intl recog. quality certification & 2.17 & 1.89 & 0.0054 \\
\hline
\end{tabular}

Sources: Authors' own work. Never is 1, Seldom is 2, Sometimes is 3, Frequently is 4, Usually is 5, Always is 6.

For all retailers, the mean value of the responses in 2008 is 2.16 , while it is 1.79 in 2013 . The difference between the responses in the crisis and post-crisis periods is statistically significant ( $\mathrm{p}<0.0001)$. "Never" is coded as 1 , "Seldom" as 2, "Sometimes" as 3, "Frequently" as 4, "Usually" as 5, and "Always" as 6. Therefore, a higher mean in 2008 (when compared to 2013) indicates that respondents believed that bribes were more common during the crisis period when compared to the post-crisis period. A score of 2.16 in 2008 is between "Seldom" and "Sometimes", while a score of 1.79 in 2013 is between "Never" and "Seldom". Therefore, we can conclude that bribes were more common during the crisis.

Differentiating the retailers with respect to the size of the firm (i.e. number of employees) reveals that, in all size groups, respondents believed that bribes were more common during the crisis. For firms with five-to-nineteen employees, while the mean value is 2.19 during the crisis, it is 1.77 post-crisis ( $\mathrm{p}<0.0001)$. For firms with twentyto-ninety-nine employees, while the mean value is 2.09 during the crisis, it is 1.80 post-crisis $(p<0.0001)$. For firms with more than ninetynine employees, while the mean value is 2.19 during the crisis, it is 1.79 post-crisis $(\mathrm{p}=0.0002)$.

Differentiating the retailers based on whether they were a part of a larger firm or not part of a larger firm reveals that there is no difference between the two groups in terms of the change in the responses from 2008 to 2013 . The respondents in both groups believed that bribes were more common during the crisis. For retailers that are part of a larger firm, while the mean value is 2.08 during the crisis, it is 1.80 post-crisis $(\mathrm{p}=0.0041)$. For firms that are not part of a larger firm, while the mean value is 2.17 during the crisis, it is 1.79 post-crisis $(\mathrm{p}<0.0001)$.

Differentiating the retailers based on their legal status (shareholding firm with shares trading in the market, shareholding firm with shares traded privately, sole proprietorship, partnership, etc.) reveals that, for all groups, bribes were seen as more common during the crisis period. The differences between the responses in 2008 and 2013 are all statistically significant for all groups. 
Differentiating the retailers based on the gender of their owners reveals that owners' gender does not make any difference. Firms that have one or more female owner and firms with no female owner both believed that bribes were more common during the crisis. For both groups, the differences are statistically significant.

Differentiating the retailers based on the gender of their top manager reveals that top manager's gender does not make any difference. Firms that have a female top manager and firms with a male top manager both believed that bribes were more common during the crisis. For both groups, the differences are statistically significant.

Finally, differentiating the retailers based on whether or not they hold an internationally recognized quality certification (i.e. ISO 9000, 9002, 14000, etc.) reveals that holding a quality certification does not make any difference. Both groups believed that bribes were more common during the crisis. For both groups, the differences are statistically significant.

To summarize, Table 2 shows that for all classifications of retailers, the respondents believed that the incidence of bribes went down significantly after the crisis ended. This is true for most types of firms (based on size, structure, legal status, owner or top manager's gender, etc.). Table 3 shows the results of the responses given to the second question which is related to the incidence of bribes in customs/imports.

For all retailers, the mean value of the responses in 2008 is 1.61 , while it is only 1.50 in 2013 . The difference between the responses in the crisis and post-crisis periods is statistically significant $(\mathrm{p}=0.0038)$. A higher mean in 2008 (when compared to 2013) indicates that respondents believed that bribes were more common in customs/imports during the crisis period when compared to the post-crisis period.

Table 3. Retailers Pay to Deal With Customs/Imports?

\begin{tabular}{|c|c|c|c|}
\hline \multicolumn{4}{|c|}{ Wilcoxon Test } \\
\hline & 2008 & 2013 & p-value \\
\hline all & 1.61 & 1.50 & 0.0038 \\
\hline employees5-19 & 1.62 & 1.45 & 0.0015 \\
\hline employees20-99 & 1.59 & 1.56 & 0.2933 \\
\hline employees $>99$ & 1.59 & 1.53 & 0.3089 \\
\hline part of a larger firm & 1.62 & 1.52 & 0.2000 \\
\hline not part of a larger firm & 1.60 & 1.49 & 0.0061 \\
\hline shareholding firm trading in the stock market & 1.63 & 1.53 & 0.4074 \\
\hline shareholding firm shares traded privately & 1.64 & 1.52 & 0.0081 \\
\hline sole proprietorship & 1.53 & 1.41 & 0.0824 \\
\hline partnership & 1.55 & 1.53 & 0.3535 \\
\hline limited partnership & 1.64 & 1.05 & 0.0011 \\
\hline other & 1.40 & 1.29 & 0.2683 \\
\hline one or more female owner & 1.51 & 1.43 & 0.0593 \\
\hline no female owner & 1.67 & 1.54 & 0.0145 \\
\hline top manager female & 1.51 & 1.42 & 0.0363 \\
\hline top manager not female & 1.64 & 1.53 & 0.0220 \\
\hline firm without an intl recog. quality certification & 1.61 & 1.47 & 0.0004 \\
\hline firm with an intl recog. quality certification & 1.57 & 1.61 & 0.1987 \\
\hline
\end{tabular}

Sources: Authors' own work. Never is 1 , Seldom is 2, Sometimes is 3, Frequently is 4, Usually is 5, Always is 6.

Differentiating the retailers with respect to the size of the firm (i.e. number of employees) reveals that, in only the smallest firm group, respondents believed that bribes were more common in customs/imports during the crisis. For firms with five-to-nineteen employees, while the mean value is 1.62 during the crisis, it is only 1.45 postcrisis $(\mathrm{p}=0.0015)$. We are not seeing any significant change from 2008 to 2013 for the other two size groups. For firms with twenty-to-ninetynine employees, while the mean value is 1.59 during the crisis, it is 1.56 post-crisis $(\mathrm{p}=0.2933)$. For firms with more than ninetynine employees, while the mean value is 1.59 during the crisis, it is 1.53 post-crisis $(\mathrm{p}=0.3089)$. These results indicate that while the respondents in the smallest size group believed that bribes were more common in customs/imports during the crisis, the other respondents did not see any difference between 2008 and 2013. 
Differentiating the retailers based on whether they were a part of a larger firm or not part of a larger firm reveals that only the respondents in the retailers that are not part of a larger firm believed that bribes were more common in customs/imports during the crisis. The other group did not see a significant difference between 2008 and 2013. For retailers that are part of a larger firm, while the mean value is 1.62 during the crisis, it is 1.52 post-crisis $(p=0.2000)$. For firms that are not part of a larger firm, while the mean value is 1.60 during the crisis, it is 1.49 post-crisis $(\mathrm{p}=0.0061)$.

Differentiating the retailers based on their legal status (shareholding firm with shares trading in the market, shareholding firm with shares traded privately, sole proprietorship, partnership, etc.) reveals that, for some groups (i.e. shareholding firms with shares traded privately, sole proprietorships and limited partnerships), bribes in customs/imports were seen as more common during the crisis period, while for others, they were not.

Differentiating the retailers based on the gender of their owners reveals that owners' gender does not make any difference. Firms that have one or more female owner and firms with no female owner both believed that bribes in customs/imports were more common during the crisis. For both groups, the differences are statistically significant.

Differentiating the retailers based on the gender of their top manager reveals that top manager's gender does not make any difference. Firms that have a female top manager and firms with a male top manager both believed that bribes in customs/imports were more common during the crisis. For both groups, the differences are statistically significant.

Finally, differentiating the retailers based on whether or not they hold an internationally recognized quality certification (i.e. ISO 9000, 9002, 14000, etc.) reveals that holding a quality certification makes a difference. Only the respondents in the retailers that did not hold a quality certification believed that bribes in customs/imports were more common during the crisis.

To summarize, Table 3 shows that for most classifications of retailers, the respondents believed that the incidence of bribes in customs/imports went down significantly after the crisis ended.

Table 4 shows the results of the responses given to the third question which is related to the incidence of bribes in courts.

Table 4. Retailers Pay to Deal With Courts?

\begin{tabular}{|c|c|c|c|}
\hline \multicolumn{4}{|c|}{ Wilcoxon Test } \\
\hline & 2008 & 2013 & p-value \\
\hline all & 1.57 & 1.40 & $<0.0001$ \\
\hline employees5-19 & 1.58 & 1.36 & $<0.0001$ \\
\hline employees20-99 & 1.57 & 1.43 & 0.0964 \\
\hline employees $>99$ & 1.54 & 1.42 & 0.1896 \\
\hline part of a larger firm & 1.52 & 1.38 & 0.0410 \\
\hline not part of a larger firm & 1.58 & 1.40 & $<0.0001$ \\
\hline shareholding firm trading in the stock market & 1.67 & 1.34 & 0.0473 \\
\hline shareholding firm shares traded privately & 1.58 & 1.41 & 0.0003 \\
\hline sole proprietorship & 1.60 & 1.34 & 0.0077 \\
\hline Partnership & 1.40 & 1.45 & 0.3661 \\
\hline limited partnership & 1.49 & 1.05 & 0.0095 \\
\hline other & 1.40 & 1.27 & 0.1283 \\
\hline one or more female owner & 1.50 & 1.35 & 0.0042 \\
\hline no female owner & 1.62 & 1.42 & 0.0005 \\
\hline top manager female & 1.51 & 1.36 & 0.0108 \\
\hline top manager not female & 1.59 & 1.41 & 0.0002 \\
\hline firm without an intl recog. quality certification & 1.59 & 1.37 & $<0.0001$ \\
\hline firm with an intl recog. quality certification & 1.44 & 1.51 & 0.0815 \\
\hline
\end{tabular}

Sources: Authors' own work. Never is 1 , Seldom is 2, Sometimes is 3, Frequently is 4, Usually is 5, Always is 6. 
For all retailers, the mean value of the responses in 2008 is 1.57 , while it is only 1.40 in 2013 . The difference between the responses in the crisis and post-crisis periods is statistically significant $(p<0.0001)$. A higher mean in 2008 (when compared to 2013) indicates that respondents believed that bribes in courts were more common during the crisis period when compared to the post-crisis period.

Differentiating the retailers with respect to the size of the firm (i.e. number of employees) reveals that, except for the largest size group (i.e. retailers with more than ninetynine employees), the respondents believed that bribes in courts were more common during the crisis.

Differentiating the retailers based on whether they were a part of a larger firm or not part of a larger firm reveals that there is no difference between the two groups in terms of the change in the responses from 2008 to 2013. The respondents in both groups believed that bribes in courts were more common during the crisis.

Differentiating the retailers based on their legal status (shareholding firm with shares trading in the market, shareholding firm with shares traded privately, sole proprietorship, partnership, etc.) reveals that, for most groups (i.e. except for partnerships and the "other" group), bribes in courts were seen as more common during the crisis period.

Differentiating the retailers based on the gender of their owners reveals that owners' gender does not make any difference. Firms that have one or more female owner and firms with no female owner both believed that bribes in courts were more common during the crisis. For both groups, the differences are statistically significant.

Differentiating the retailers based on the gender of their top manager reveals that top manager's gender does not make any difference. Firms that have a female top manager and firms with a male top manager both believed that bribes in courts were more common during the crisis. For both groups, the differences are statistically significant.

Finally, differentiating the retailers based on whether or not they hold an internationally recognized quality certification (i.e. ISO 9000, 9002, 14000, etc.) reveals that the respondents in the firms that did not hold a quality certification believed that bribes in courts were more common during the crisis, while the opposite is true for the other group. The respondents in the firms that held a quality certification believed that bribes in courts were less common during the crisis. For both groups, the differences are statistically significant.

To summarize, Table 4 shows that for most classifications of retailers, the respondents believed that the incidence of bribes in courts went down significantly after the crisis ended.

Table 5 shows the results of the responses given to the fourth question which is related to the incidence of bribes in taxes and tax collection.

For all retailers, the mean value of the responses in 2008 is 1.80 , while it is 1.57 in 2013 . The difference between the responses in the crisis and post-crisis periods is statistically significant ( $\mathrm{p}<0.0001)$. A higher mean in 2008 (when compared to 2013) indicates that respondents believed that bribes in taxes/tax collection were more common during the crisis period when compared to the post-crisis period.

Table 5. Retailers Pay to Deal With Taxes and Tax Collection?

\begin{tabular}{|c|c|c|c|}
\hline \multicolumn{4}{|c|}{ Wilcoxon Test } \\
\hline & 2008 & 2013 & p-value \\
\hline all & 1.80 & 1.57 & $<0.0001$ \\
\hline employees5-19 & 1.83 & 1.56 & $<0.0001$ \\
\hline employees20-99 & 1.72 & 1.60 & 0.0714 \\
\hline employees $>99$ & 1.83 & 1.45 & $<0.0001$ \\
\hline part of a larger firm & 1.74 & 1.60 & 0.0150 \\
\hline not part of a larger firm & 1.80 & 1.56 & $<0.0001$ \\
\hline shareholding firm trading in the stock market & 2.01 & 1.46 & 0.0041 \\
\hline shareholding firm shares traded privately & 1.76 & 1.58 & $<0.0001$ \\
\hline sole proprietorship & 1.82 & 1.55 & 0.0049 \\
\hline partnership & 1.56 & 1.64 & 0.3875 \\
\hline limited partnership & 2.05 & 1.05 & $<0.0001$ \\
\hline
\end{tabular}


Table 5 (cont.). Retailers Pay to Deal With Taxes and Tax Collection?

\begin{tabular}{|c|c|c|c|}
\hline \multicolumn{4}{|c|}{ Wilcoxon Test } \\
\hline & 2008 & 2013 & p-value \\
\hline Other & 1.46 & 1.49 & 0.3804 \\
\hline one or more female owner & 1.76 & 1.52 & $<0.0001$ \\
\hline no female owner & 1.83 & 1.60 & $<0.0001$ \\
\hline top manager female & 1.73 & 1.50 & $<0.0001$ \\
\hline top manager not female & 1.82 & 1.60 & $<0.0001$ \\
\hline firm without an intl recog. quality certification & 1.83 & 1.54 & $<0.0001$ \\
\hline firm with an intl recog. quality certification & 1.66 & 1.67 & 0.3119 \\
\hline
\end{tabular}

Sources: Authors' own work. Never is 1, Seldom is 2, Sometimes is 3, Frequently is 4, Usually is 5, Always is 6.

Differentiating the retailers with respect to the size of the firm (i.e. number of employees) reveals that, in all size groups, respondents believed that bribes in taxes/tax collection were more common during the crisis.

Differentiating the retailers based on whether they were a part of a larger firm or not part of a larger firm reveals that there is no difference between the two groups in terms of the change in the responses from 2008 to 2013. The respondents in both groups believed that bribes were more common in taxes/tax collection during the crisis.

Differentiating the retailers based on their legal status (shareholding firm with shares trading in the market, shareholding firm with shares traded privately, sole proprietorship, partnership, etc.) reveals that, for most groups (i.e. except for partnerships and the "other" group), bribes in taxes/tax collection were seen as more common during the crisis period.

Differentiating the retailers based on the gender of their owners reveals that owners' gender does not make any difference. Firms that have one or more female owner and firms with no female owner both believed that bribes in taxes/tax collection were more common during the crisis. For both groups, the differences are statistically significant.

Differentiating the retailers based on the gender of their top manager reveals that top manager's gender does not make any difference. Firms that have a female top manager and firms with a male top manager both believed that bribes in taxes/tax collection were more common during the crisis. For both groups, the differences are statistically significant.

Finally, differentiating the retailers based on whether or not they hold an internationally recognized quality certification (i.e. ISO 9000, 9002, 14000, etc.) reveals that the respondents in the firms that did not hold a quality certification believed that bribes in courts were more common during the crisis, while the same cannot be said for the other group. The respondents in the firms that held a quality certification did not see a significant difference between 2008 and 2013.

To summarize, Table 5 shows that for most classifications of retailers, the respondents believed that the incidence of bribes in taxes/tax collection went down significantly after the crisis ended.

Table 6 shows the results of the regression that explains the frequency of the additional payments made in customs, taxes, licenses, regulations, etc. The regression equation is shown below:

Paid $=\mathrm{c}_{0}+\mathrm{c}_{1}$ (post-crisis $)+\mathrm{c}_{2}($ larger firm $)+\mathrm{c}_{3}($ not part of a larger firm $)+\mathrm{c}_{4}($ no female owner $)+\mathrm{c}_{5}($ top manager male $)+\mathrm{c}_{6}($ no intl certification $)+\varepsilon_{\mathrm{t}}$

The results show that, after controlling for firm characteristics including size, whether the firm is a part of a larger firm, gender of the owner, gender of the top manager, and whether the firm has an international certification, "post-crisis" has a negative and significant impact on the frequency of the additional payments made (coefficient $=-0.3640, \mathrm{p}<0.0001$ ). The other independent variables (i.e. the control variables) are statistically insignificant. 
Table 6. Regression Predicting The Frequency Of Additional Payments Made

\begin{tabular}{|l|c|c|}
\hline Independent variables & \multicolumn{1}{|c|}{ Additional Payment vs No Additional Payment } \\
\hline & Coefficient & p-value \\
\hline Intercept & 2.0166 & $<0.0001$ \\
\hline post-crisis & -0.3640 & 0.0001 \\
\hline larger firm & 0.0135 & 0.5688 \\
\hline not part of a larger firm & 0.0470 & 0.4242 \\
\hline no female owner & 0.0015 & 0.9086 \\
\hline top manager male & 0.0180 & 0.4371 \\
\hline no intl certification & 0.0002 & 0.9816 \\
\hline $\mathrm{N}$ & & \\
\hline
\end{tabular}

Source: Authors' own work.

\section{Conclusion}

In this study therefore, we attempt to address four questions, including: Did the overall incidence of bribes went down after the crisis ended? Did the incidence of bribes in customs/imports went down after the crisis ended? Did the incidence of bribes in courts went down after the crisis ended? Did the incidence of bribes in taxes and tax collection went down after the crisis ended?

Overall, we find that retail firms believed that the overall bribes were significantly higher during the crisis period when compared to the post-crisis period, and conclude that bribes were more common during the crisis. The same results hold even when we classify the companies based on different types including firm size (i.e. number of employees), whether they were a part of a larger firm or not part of a larger firm, based on their legal status (shareholding firm with shares trading in the market, shareholding firm with shares traded privately, sole proprietorship, partnership, etc.), based on the gender of their owners, based on the gender of their top manager, and based on whether or not they hold an internationally recognized quality certification (i.e. ISO 9000, 9002, 14000 , etc.).

When we examine whether the incidence of bribes in customs/imports went down after the crises, we find that for all retailers, respondents believed that bribes were more common in customs/imports during the crisis period. In addition, we find that respondents in the smallest size group, respondents who were not part of a larger firm, several types of companies based on legal status (i.e. shareholding firms with shares traded privately, sole proprietorships and limited partnerships), gender of owners and managers, and companies without internationally recognized quality certification also perceived bribes in customs/imports as less common after the crisis.

As for the incidence of bribes in courts, we find that overall, respondents believed that bribes in courts were less common after the crisis ended. The results hold when we differentiate respondents with respect to firm size, whether they were a part of a larger firm or not, based on their legal status (except for partnerships and the "other" group), based on the gender of their owners or top manager, or when they did not hold an internationally recognized quality certification.

Finally, we also find that respondents believed that bribes in taxes/tax collection were less common after the crisis. There is also no significant difference when we group the retailers based on firm size, based on whether they were a part of a larger firm or not, based on their legal status (except for partnerships and the "other" group), and based on the gender of their owners or top manager. In other words, for bribes in taxes/tax collection, the respondents believed that the incidence of bribes in taxes/tax collection went down significantly after the crisis ended.

Therefore, in general, for retail firms in the sample countries, respondents believed that bribes were more common during the crisis than after the crisis, regardless of the type of the bribes (i.e. customs/imports, courts, and taxes/tax collection) and characteristics of the firms (e.g. firm size, legal status, gender of owners or top manager, holding quality certification, and part of larger firm). However, the results do not hold for some of the classifications (i.e. medium-sized and the largest small firms, the firms that are part of a larger firm, the shareholding firms trading in the market, the partnerships, and the firms with an internationally recognized quality certification). Also, for 
bribes in courts, the results do not hold for the largest small firms and the partnerships, and for bribes in taxes/tax collection, the results do not hold for the partnerships and the firms with a quality certification.

The findings of this study seem to be consistent with the low rankings of countries in Eastern Europe and Central Asia in the Corruption Perceptions Index (CPI) published annually by Transparency International, including both in 2008 and 2013. Our findings also seem to be consistent with prior studies which documented corruption in developing and less developed countries, which suggests that much remains to be done in order to change the perception of corruption in these regions.

Funding: self-funded.

Author contribution: conceptualization, Halil Dincer Kaya and Engku Ngah S. Engkuchik; data curation: Halil Dincer Kaya and Engku Ngah S. Engkuchik; formal analysis: Halil Dincer Kaya and Engku Ngah S. Engkuchik; funding acquisition: Halil Dincer Kaya and Engku Ngah S. Engkuchik; investigation: Halil Dincer Kaya and Engku Ngah S. Engkuchik; methodology: Halil Dincer Kaya and Engku Ngah S. Engkuchik; project administration: Halil Dincer Kaya and Engku Ngah S. Engkuchik; resources: Halil Dincer Kaya and Engku Ngah S. Engkuchik; software: Halil Dincer Kaya and Engku Ngah S. Engkuchik; supervision: Halil Dincer Kaya and Engku Ngah S. Engkuchik; validation: Halil Dincer Kaya and Engku Ngah S. Engkuchik; visualization: Halil Dincer Kaya and Engku Ngah S. Engkuchik; writing - original draft: Halil Dincer Kaya and Engku Ngah S. Engkuchik; writing - review \& editing: Halil Dincer Kaya and Engku Ngah S. Engkuchik.

\section{References}

1. Aidt, T. S. (2003). Economic analysis of corruption: A survey, The Economic Journal, 113(491), 632-652. Available at: [Link].

2. Anokhin, S., \& Schulze, W. S. (2009). Entrepreneurship, innovation, and corruption, Journal of Business Venturing, 24(5), 465-476. Available at: [Link].

3. Bardhan, P. (1997). Corruption and development: a review of issues, Journal of Economic Literature, 35(3), 1320-1346. Available at: [Google Scolar], [Link].

4. Drury, A. C., Krieckhaus, J., and Lusztig, M. (2006). Corruption, democracy, and economic growth, International Political Science Review, 27(2), 121-136. Available at: [Google Scholar], [Link].

5. Glaeser, E. L., \& Saks, R. E. (2006). Corruption in America, Journal of Public Economics, 90(6), 1053-1072. Available at: [Google Scholar], [Link].

6. Gould, D. J., \& Amaro-Reyes, J. A. (1983). The effects of corruption on administrative performance. World Bank Staff Working Paper No. 580, Available at: [Link].

7. Henderson, J. V., \& Kuncoro, A. (2004). Corruption in Indonesia, NBER Working Paper 10674, National Bureau of Economic Research. Available at: [Link].

8. Jain, A. K. (2001). Corruption: A review. Journal of Economic Surveys, 15(1), 71-121. [CrossRef].

9. Kapur, D., and Vaishnav, M. (2013). Quid pro quo: Builders, politicians, and election finance in India. Kapur, Devesh and Vaishnav, Milan, Quid Pro Quo: Builders, Politicians, and Election Finance in India, Center for Global Development Working Paper No. 276. [CrossRef].

10. Kronenberg, T. (2004). The curse of natural resources in the transition economies. Economics of Transition, 12(3), 399-426. Available at: [Google Scholar], [Link].

11. Leite, C., and Weidmann, J. (1999). Does mother nature corrupt? Natural resources, corruption, and economic growth, IMF Working Paper No. 99/85. Available at: [Link].

12. Mauro, P. (1998). Corruption: causes, consequences, and agenda for further research, Finance and Development, 35(1), 11-14. Available at: [Google Scholar], [Link].

13. Mbaku, J. M. (1996). Bureaucratic corruption in Africa: The futility of cleanups, The Cato Journal, 16(1), 99-118. Available at: [Link].

14. Ngunjiri, I. (2010). Corruption and entrepreneurship in Kenya. Journal of Language, Technology \& Entrepreneurship in Africa, 2(1), 93-106. Available at: [Google Scholar], [Link]. 
15. Osei-Tutu, E., Badu, E., and Owusu-Manu, D. (2010). Exploring corruption practices in public procurement of infrastructural projects in Ghana, International Journal of Managing Projects in Business, 3(2), 236-256. [CrossRef].

16. Pellegrini, L. (2011). Economic analysis of corruption. In Corruption, Development and the Environment, Netherlands: Springer, 13-27. [CrossRef].

17. Safavian, M. S., Graham, D. H., \& Gonzalez-Vega, C. (2001). Corruption and microenterprises in Russia, World Development, 29(7), 1215-1224. Available at: [Google Scholar], [Link].

18. Svensson, J. (2005). Eight questions about corruption. The Journal of Economic Perspectives, 19(3), 19-42.. [CrossRef].

19. Tanzi, V., and Davoodi, H.R. (1997). Corruption, Public Investment, and Growth, IMF Working Paper No. 97/139. Available at: [Google Scholar], [Link].

20. Tonoyan, V., Strohmeyer, R., Habib, M., \& Perlitz, M. (2010). Corruption and entrepreneurship: How formal and informal institutions shape small firm behavior in transition and mature market economies, Entrepreneurship Theory and Practice, 34(5), 803-831. [CrossRef]. 